International Journal of Contemporary Islamic Education

Vol. 2 No. 2 Tahun 2020

\title{
Improving Emotional and Spiritual Intelligence of Students through Aqidah Morals
}

\author{
Moh Kamaluddin ${ }^{1 *}$,Adawiyah Adawiyah ${ }^{2}$, and Rusdin Rusdin ${ }^{3}$ \\ 1 Islamic Education Department, Postgraduate, Institut Agama Islam Negeri Palu \\ 2 Islamic Education Department, Postgraduate, Institut Agama Islam Negeri Palu \\ ${ }^{3}$ Islamic Education Department, Postgraduate, Institut Agama Islam Negeri Palu
}

\begin{abstract}
The aim of this paper is to discusses Improving Emotional and Spiritual Intelligence of Students through Aqidah Morals. This study uses qualitative methods and data was gathered through observation, in-depth interviews, and written material. Data analysis was analyzed using grounded theory approach. The results showed that the teacher's efforts in improving discipline, honesty, responsibility, and cooperation of students at Madrasah Aliyah 2 Palu City through learning Akidah Akhlak were carried out by providing exemplary in terms of punctual arrival in class, advice and motivation, sanctions/punishment, making students' friends as assisting teachers, applying the discussion method in learning.
\end{abstract}

ARTICLE

INFORMATION 


\section{Introduction}

In fact, the Intelligence Question (IQ) has a significant positive impact on development towards progress. However, this intelligence only touches the external realm of the human self, while the aspects of recognition and internal understanding of oneself and others, and the recognition of sincerity that comes from human nature itself cannot be reached. Someone who has spiritual intelligence (IS) or spiritual intelligence and compassion will have a commitment to others, and will be responsible for helping. ${ }^{1}$ Human quality will decline drastically without understanding the noble values of ethics, morals, and norms that govern their lives, both individually and socially. ${ }^{2}$ Of course this is an interesting thing to study, when someone cannot understand themselves, others and the lack of relationship with the Creator, so that it can have its own consequences.

In principle, emotional intelligence (IE) and spiritual intelligence (IS) cannot be ruled out because they have a big role to play in increasing the potential values contained in humans, even more important than IQ in fostering character. Especially as an effort to prepare a cultured and dignified generation of the nation. The position of emotional and spiritual

1Tony Buzan, The Power Of Spiritual Intelligence, terj. Alex Tri Kantjono W. dan Febrina Fialita, Sepuluh Cara Jadi Orang yang Cerdas secara Spiritual (Cet. II; Jakarta: Gramedia Pustaka Utama, 2003), 44.

2 Rusli, R. (2014). Teaching Usul al-Fiqh: A Multicultural Education Model. Al-Tahrir: Jurnal Pemikiran Islam, 14(2), 447-464. intelligence as a tool for learning and applying values is expected to become a habit and character that is cultured in the social environment.

Basically, emotional and spiritual intelligence is a type of intelligence that ranks at the top in the development of quality human resources by upholding the noble values of humanity as the best creature created by God and as a representative in the universe. Humans are required to live side by side with the surrounding environment in a harmonious and beneficial social interaction. This cannot be realized as expected without the support of good emotional and spiritual intelligence.

In this modern era, there are still many students who experience emotional difficulties, ranging from mild, moderate, to high-level problems that cannot be resolved. The low level of emotional and spiritual intelligence causes students to easily act aggressively, easily become anxious and easily engage in behavior that violates ethics, even there are still many cases of child violations entering the criminal area. For this reason, in the world of education, the process of building and improving the emotional and spiritual intelligence of students needs to be continuously pursued by teachers and parents. So that students who are still under guidance can be monitored for their psychological growth so that they become figures with noble character, both in the family, school, and community environment.

Basically, Islamic education in improving emotional intelligence (IE) and spiritual intelligence (IS) is a top

e-ISSN: 2715-4572

p-ISSN: 2716-1439 
priority. Efforts to increase this ability are realized through learning Akidah Akhlak based on the Qur'an and Hadith as a guide for Muslims in achieving safety and welfare in the world and the hereafter. Through learning Akidah Akhlak, the teacher's efforts to improve emotional and spiritual intelligence are carried out in a real way, in the sense that it is not only a concept but must be supported by daily behavior in the form of noble attitudes, speech and behavior based on self-awareness and sincerity in its implementation. This refers to the person of the Prophet. who have noble character, embrace others with love and tenderness. As in the word of Allah swt. (Surah Al-Qalam, [68]: 4),

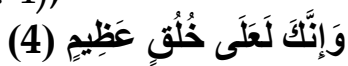

The translation: "And behold, you are truly virtuous." 3

In that verse Allah swt. explained that in Rasulullah saw. there is a noble character. His figure, which is decorated with hospitality, compassion, care, honesty, and other noble qualities, is able to deliver Islam as a religion that can be accepted by society.

Emotional and spiritual intelligence is a measure of a person's life success. Where in Islam, efforts to improve it can be done through fostering noble morals which acts as a tool for fostering good relations with Allah SWT and between each other. Without a high IQ, great success can still be achieved by exploring one's potential through learning Akidah Akhlak in

3Departemen Agama RI, Al-Qur'an dan Terjemahnya (Bandung: Syamil Cipta Media, 2006), 564. honing emotional and spiritual intelligence.

Rasulullah saw. as a reflection of noble morals which includes attitudes, speech and behavior in accordance with the objectives sent in order to perfect noble morals. History records the personal glory of Rasulallah saw who is able to combine the best relationships between oneself and others and with Allah SWT so that the planting of the teachings brought by the Prophet. regarding noble morals is the main priority for shaping the personality of a Muslim.

Learning Akidah Akhlak provides an effective way to hone the emotional and spiritual intelligence of students. The emotional and spiritual condition of students who are below standard can be pursued by the teacher to increase the ideal standard through learning Akidah Akhlak. This is reflected in the learning of Akidah Akhlak in the efforts of teachers to improve the emotional and spiritual intelligence of students at Madrasah Aliyah 2 Palu as a step in overcoming the problems faced so that the attitudes and behavior of students become better.

Based on observations in Madrasah Aliyah 2 Palu, the author got information from the teacher that the level of awareness, concern, diversity, and politeness of students was still at the lower middle level, in the sense that the level of recognition and understanding of themselves, others and worship behavior was still necessarily improved. In general, students have a knowledge base to behave as they should.

e-ISSN: 2715-4572

p-ISSN: 2716-1439 
However, on the one hand, there are still students who do not follow madrasa policies, both norms, ethics, and those relating to religious activities, such as lack of awareness of discipline, cleanliness, lack of respect for teachers, student closeness between boys and women are outside the limits of reasonableness so that they are often reprimanded by the teacher, violate the rules of congregational prayer, and do not participate in teaching and learning activities. So that there needs to be a teacher's effort in guiding and directing students to better conditions.

\section{Literature Review}

\subsection{Understanding Intelegence.}

In terms of biology, intelligence is interpreted as a basic human ability that is relatively necessary for adjustment to new surroundings. ${ }^{4}$ Even though in reality in this world there are many people who have high intelligence who are unable to adapt themselves to their surroundings properly. One of the stages in individual cognitive development is the inactive stage, where individuals carry out activities in an effort to understand the environment or the world around them with motor knowledge ${ }^{5}$

The author's point of view is that the ability to adapt and understand the natural surroundings can increase human awareness to preserve nature

${ }^{4}$ Purwa Atmaja Prawira, Psikologi Pendidikan dalam Perspektif Baru (Jogjakarta: ArRuzz Media, 2013), 137.

5P. Ratu Ile Tokan, Sumber Kecerdasan Manusia (Jakarta: Grasindo, 2016), 12. and prevent things related to natural pollution that can have a negative impact on human life.

1) Intelligence viewed psychologically

In fact, every child who is born has been gifted with the potential of intelligence which allows him to develop and survive in accordance with the nature that has been given by God the Almighty. Thomas Armstrong, an education expert from the USA argues that intelligence is represented through inherent traits, including: curiosity, exploration of the environment, spontaneity, vitality, and flexibility. ${ }^{6}$

Intelligence is seen from a psychological perspective, that in principle humans are endowed with cognitive abilities from birth which are manifested in the form of innate traits to be able to adapt to the environment in order to survive. This ability gives privileges and distinguishing factors between humans and other creatures. Related to this, heredity also has a considerable influence on children's cognitive abilities.

2) Intelligence is reviewed operationally

The definition of intelligence operationally uses statements from observed conditions so that the statement of the sentence contains the terms true or false. For example, to determine an IQ score a person must undergo an IQ test. When carrying out an IQ test behavior must be observed and the results of the test can be given a grade. The determination of a person

${ }^{6}$ Neni hermita, Rimba Hamid, M. Jaya Adipura, Achmad Samsudin, Pembelajaran Berbasis Kecerdasan Jamak di SD (Yogyakarta: Deepublish, 2017), 3.

e-ISSN: 2715-4572

p-ISSN: 2716-1439 
classified as intelligent or mediocre is used by the IQ score classification guidelines. ${ }^{7}$

\subsection{The Concept of Emotional Intelligence}

The word emotion in psychology is defined as feeling. The word emotion is used as a pronoun for feelings so that the individual's condition when angry, sad, disappointed, or happy is part of the emotion. The word emotion includes not only feelings of anger or sadness, but everything that concerns human feelings. ${ }^{8}$

The term "emotional intelligence" was first coined in 1990 by psychologists Peter Salovey of Harvard University and John Mayer of the University of New Hampshire to describe emotional qualities that appear to be essential to success. These qualities include "empathy, expressing and understanding feelings, controlling anger, independence, adaptability, liking, interpersonal problem solving skills, persistence, solidarity, kindness, and respect." 9

A psychologist from New York, United States named Daniel Goleman, views that emotional intelligence is a person's extra ability to motivate oneself, resilience in the face of failure, control

\footnotetext{
7Purwa Atmaja Prawira, Psikologi Pendidikan dalam Perspektif Baru, 139.

${ }^{8} \mathrm{Al}$. Tridhonanto, Melejitkan Kecerdasan Emosi (EQ) Buah Hati (Jakarta: Elex Media Komputindo, 2009), 2.

${ }^{9}$ Lawrence E. Shapiro, How to Raise A Child with A Hagh EQ-A Parents Guide to Emotional Intelligence, terj. Alex Tri Kantjono, Mengajarkan Emotional Intelligence pada Anak (Cet. VI; Jakarta: Gramedia Pustaka Utama, 2003), 5.
}

emotions and delay gratification, and regulate the state of the soul. ${ }^{10}$

Meanwhile, according to Ary Ginanjar Agustian, "Emotional intelligence can be defined as the ability to feel, understand, and effectively apply emotional power and sensitivity as a source of energy, information, connections and human influence. ${ }^{11}$

Based on the explanation above, it can be understood that emotional intelligence is a person's ability to recognize and understand oneself in the form of awareness to solve problems in life. The descriptions of self-recognition and understanding are contained in the form of priorities for self-motivation to create positive feelings of the heart, mental strength in dealing with life's problems. Apart from encouragement, management of one's own psychological condition is also the key to a person's emotional ability to be able to control various emotional fluctuations that arise, so that they can return to a stable condition, in the sense that actions that can destroy ethical values can be avoided. In addition, emotional intelligence also includes the social realm which is expressed in the form of empathy for others. As social beings, interaction with others is behavior that cannot be avoided. Therefore, it is necessary to have an empathetic attitude towards the suffering of others to be able to act wisely in society.

${ }^{10} \mathrm{Al}$. Tridhonanto, Melejitkan Kecerdasan Emosi (EQ) Buah Hati, 4.

${ }^{11}$ Ary Ginanjar Agustian, Rahasia Sukses Membangkitkan ESQ Power Sebuah Inner Journey Melalui Al-Ihsan (Jakarta: Arga, 2003), 199.

e-ISSN: 2715-4572

p-ISSN: 2716-1439 
2.3 The role of emotional intelligence

Emotional intelligence gives great hope in achieving a person's life success, as stated by Daniel Goleman, according to him, "People with well-developed emotional skills mean that they are likely to be happy and successful in life."12

Often found in the community, someone who can be a great success because he / she has high emotional intelligence even with low academic intelligence (cognitive) abilities. This situation shows that academic intelligence (cognitive) is not a measure of a person's success.

Even with a high IQ, a person is not necessarily able to overcome selfproblems. In fact, he can fail to recognize himself. On the other hand, there are people with an ordinary IQ in life, they can have great success because they have a high sense of emotionality or IE. ${ }^{13}$

From this perspective, it can be understood that emotional intelligence cannot be underestimated. Its big role in life encourages this intelligence to be prioritized as the intellectual abilities that have been favored from classical times.

\subsection{The Concept of Spiritual Intelligence}

In this section, an aspect that is no less important than IQ and EQ in achieving life success will be presented. The position of this aspect is considered as a great energy and driving force for

${ }^{12}$ Daniel Goleman, Emotional Intelligence, terj. T. Hermaya, Kecerdasan Emosional (Jakarta: Gramedia Pustaka Utama, 1996), 48.

13Purwa Atmaja Prawira, Psikologi Pendidikan dalam Perspektif Baru, 151.
IQ and EQ in humans. So there is no reason to rule out the discussion of this section in order to foster and improve the quality of the individual towards a whole human figure.

According to Danah Zohar and Ian Marshall, what is meant by spiritual intelligence is

Intelligence to deal with and solve problems of meaning and value, namely intelligence to place our behavior and life in a broader and richer context of meaning, intelligence to judge that one's actions or way of life are more meaningful than others. ${ }^{14}$

Meanwhile Prima Vidya Asteria said that spiritual intelligence is "human intelligence used to relate to God". ${ }^{15}$ It can be understood that spiritual intelligence is an intelligence that places human behavior and life in a more meaningful position, both in establishing relationships with others and with God.

Furthermore, Danah Zohar and Ian Marshal assert that spiritual intelligence can foster a person's human function so as to make them creative, flexible, broad-minded, spontaneous, able to face life's struggles, deal with anxiety and worry, can bridge between

${ }^{14}$ Danah Zohar dan Ian Marshall, SQ: Spiritual Intelligence-The Ultimate Intelligence, terj. Rahmani Astuti, SQ: Memanfaatkan Kecerdasan Spiritual dalam Berpikir Integralistik dan Holistik untuk Memaknai Kehidupan (Bandung: Mizan, 2002), 4 .

15Prima Vidya Asteria, Mengembangkan Kecerdasan Spiritual Anak Melalui Pembelajaran Membaca Sastra, 21. 
themselves and others, and become smarter. spiritually in religion. ${ }^{16}$

The views of Danah Zohar and Ian Marshal point to significant benefits for human spiritual abilities. The benefits in question are the creation of behavioral changes in the cognitive, affective, and psychomotor aspects which are the goals of learning. In addition, they have skills and competitiveness in a social environment, are able to face the dynamics of life with various problems that arise, and have a quality religious attitude ${ }^{17}$.

The awareness of values presented in the rhythm of the spirit of religious spirituality does not only function as an explanation of the mystical esoteric region, but more than that it requires the involvement of a sense to understand it. ${ }^{18}$ Therefore, in Sufi psychology, the heart (in its various levels) always takes a higher place than reason and desire because the heart has a very decisive position in the human nafsani system. ${ }^{19}$

\footnotetext{
16Purwa Atmaja Prawira, Psikologi Pendidikan dalam Perspektif Baru, 168.

17 Rusli, R. (2018). Fikih Ekologi dan Kearifan Tradisional: Tinjauan Terhadap Konsep Ihya' al-Mawat dan Hima. Hunafa: Jurnal Studia Islamika, 5(3), 287-298.

18 Evita, E., Syahid, A., \& Nurdin, N. (2019). Understanding Students' Learning Outcomes Differences Through the Application of the Market Place Activity Type of Cooperative Learning Model and the Application of Conventional Learning Models International Journal of Contemporary Islamic Education, 1(1), 6785.

${ }^{19}$ Maksudin, Desain Pengembangan Berpikir Integratif Interkonektif Pendekatan Dialektik (Yogyakarta: Pustaka Pelajar, 2015), 31.
}

Spiritual intelligence plays a controlling and empowering role, by accessing emotional intelligence and intellectual intelligence. In addition, spiritual intelligence also controls and empowers physical intelligence in a very vital part, namely the subtle-neurotransmitter and neurohormonal. The two nerves are in charge of controlling the function and performance of cells and the brain, which greatly affects immunity and body aging. ${ }^{20}$

\section{Methodology}

This study used a qualitative approach with the object of research, namely Madrasah Aliyah 2 Palu. The reason the authors chose madrasah aliyah as the research location is because this madrasah aliyah is an Islamic education institution (madrasah) equivalent to High School in Central Sulawesi which is a model in various aspects for other madrasahs.

The use of qualitative methods in this study has several considerations. First, adapting qualitative methods is easier when faced with multiple realities. Second, it can directly present the nature of the relationship between researchers and informants. ${ }^{21}$ Third, this method is more sensitive and adapts itself to a lot of sharpening a common guide and to the value patterns faced. ${ }^{22}$

${ }^{20}$ Budi Yuwono, SQ Reformation: Rahasia Pribadi Cerdas Spiritual "Genius Hakiki" (Jakarta: Gramedia Pustaka Utama, 2010), 124.

${ }^{21}$ Nurdin, N. (2017a). Research in Online Space: The Use of Social Media for Research Setting Jurnal Sistem Informasi (Journal of Information System), 13(1), 67-77.

22Ibid., 5.

e-ISSN: 2715-4572

p-ISSN: 2716-1439 
Data were collected using observation techniques, in-depth interviews ${ }^{23}$ with principals, teachers, and students. Researchers also reviewed various written documents. ${ }^{24}$ Meanwhile, data analysis was carried out using reduction and verification techniques with various data sources. ${ }^{25}$ The data that has been reduced is then analyzed by confessing the theoretical concepts used in this study.

\section{Result and Discussion}

\subsection{Teacher's Efforts to Increase Emotional and Spiritual Intelligence}

A developed nation is a nation that has quality human resources. This is difficult to happen without the intervention of the teacher as the main intermediary. Teachers are educators who contribute to advancing a nation with dignity, both intellectually, emotionally, and spiritually.

23 Nurdin, N., \& Yusuf, K. (2020). Knowledge management lifecycle in Islamic bank: the case of syariah banks in Indonesia. International Journal of Knowledge Management Studies, 11(1), 59-80.

https://doi.org/10.1504/ijkms.2020.105073

24 Nurdin, N. (2017b). To Research Online or Not to Research Online: Using Internet-Based Research in Islamic Studies Context. Indonesian Journal of Islam and Muslim Societies, 7(1), 31-54.

25 Nurdin, N. (2016). The Roles of Information Technology in Islamic Bank Knowledge Management: A study of Two Syariah Banks in Palu. Hunafa: Jurnal Studia Islamika 13(2),

181-217.

https://doi.org/https://doi.org/10.24239/jsi.v1 3i2.444.181-217
The teacher's dedication in striving for students to become individuals who have noble character, are able to recognize themselves, have empathy for others, are responsible, and know the main purpose of life. This makes the teacher a person who needs to be remembered for his services.

Akidah Akhlak teachers have an important role as a guide in instilling and increasing the moral values of students. This role is a noble duty of a teacher who requires patience in its implementation to produce a person with noble character.

According to Mr. Muhammad Anas, that:

Akidah Akhlak teachers are different from teachers of other subjects, because Akidah Akhlak teachers lead to children's character, so I ask the Akidah Akhlak teachers to instill in children several things, the first is about honesty, discipline, responsibility and behavior in everyday life, the second is about speech, if there are children who are too far from their words to be called and immediately reprimanded, because this is a matter of morals. ${ }^{26}$

The results of the interview above provide an illustration that the Akidah Akhlak teacher has certain specifications, because it is in direct contact with the character of the students. When talking about character, the dominant one is the Akidah Akhlak teacher, where morality is one of the important foundations in shaping and

26Muhammad Anas, Kepala MAN 2 Kota Palu, "Wawancara", di ruang Kepala Madrasah, tanggal 23 Oktober 2019.

e-ISSN: 2715-4572

p-ISSN: 2716-1439 
enhancing a person with noble character, to create a devout human being and a true Muslim. By learning Akidah Akhlak, it is hoped that every student will be able to apply it in everyday life. Learning Akidah Akhlak can lead to the level of moral dignity, because with this learning students become increasingly aware of their position and duties as a student.

Cultivating and enhancing moral values is very important in Islamic education. In this case, the teacher does not only function as a teacher but also acts as a parent in the development of their students. Akidah Akhlak teachers are figures who are responsible for the development of students by striving for all their potential, especially in terms of honesty, discipline, and responsibility which is a description of their emotional and spiritual skills. Therefore, Akidah Akhlak teachers need to have steps as an effort to increase noble morals, especially in terms of honesty, discipline, and responsibility.

This was conveyed by Mrs. Ukhriyah Zam Anwar, one of the Akidah Akhlak teachers, according to her:

Students need to know about the importance of being disciplined, honest, and responsible which are parts of noble morals that need to be applied in everyday life and how noble morals can make a major contribution to the success of one's life. ${ }^{27}$

Ibu Ukhriyah Zam Anwar's statement shows that students are

27Ukhriyah Zam Anwar,Guru Akidah Akhlak, "Wawancara", di ruang guru, tanggal 18 September 2019. required to be disciplined, honest, and responsible. In addition, students need to know the great contribution of noble morals in supporting the success of life. Morals, which are described as the spirit of Islam, have an important meaning in the activities undertaken by students in general.

Referring to the explanation above, according to the author, moral learning is a way that students need to go through in increasing emotional and spiritual intelligence based on Islamic teachings, in this case discipline, honesty, and responsibility. This method is more specific because it has clear guidelines by referring to the contents of the Qur'an and hadiths that direct each individual to know himself, cleanse himself (tadzkiyatunnafsi), and fight lust (mujahadatunnafsi) with a series of rituals in achieving divine pleasure.

The large contribution of noble morals in achieving one's life success is judged in accordance with the views of Daniel Goleman, Danah Zohar, and Ian Marshal who prioritize emotional and spiritual intelligence over cognitive intelligence, where someone who has this intelligence is likely to get happiness. However, it has been stated that in the Islamic perspective, morals are the means by which to build and enhance emotional and spiritual abilities in a more specific and directed way with a clear theological foundation.

Discipline, responsibility, honesty, and cooperation should be able to be practiced in the daily lives of students. These attitudes are part of spiritual emotional intelligence, where there are seven basic values of emotional

e-ISSN: 2715-4572

p-ISSN: 2716-1439 
and spiritual intelligence in the Islamic perspective of Ary Ginanjar Agustian characterized by the values of honesty, responsibility, discipline, cooperation, care, justice, and visionary. The importance of these characteristics for students in living life, the teacher needs to convey to inspire the students' souls to have praiseworthy qualities.

The Akidah Akhlak teacher, in this case Mrs. Minarni, conveyed the importance of these traits possessed by every student, according to her:

In class XI there is no material about discipline, responsibility, honesty, cooperation, but when the learning takes place I often convey it to the prologue or lesson opening, with the hope that this character is in them in learning. I give motivation to children about discipline, their responsibility is that all tasks must be completed.28

Referring to the interview above, even though in class XI the material regarding these characteristics does not exist in the Akidah Akhlak learning, the teacher always delivers it to the lesson opening by providing motivation with hope that students are able to live and realize it in the form of daily attitudes and behavior.

Based on observations and interviews with informants in the field and supported by related data, the authors found several problems regarding the emotional and spiritual intelligence of students in class XI social

28Minarni, Guru Akidah Akhlak, "Wawancara", di Ruang Guru, Tanggal 18 Januari 2020. science-science 2 Madrasah Aliyah 2 Palu, among the problems, namely: discipline, honesty, responsibility, and cooperation.

\section{a. Discipline}

Discipline conditions of students in class XI social science 2 still need to be improved, this can be seen from the attendance list of Akidah Akhlak lessons in the odd semester of the 2019/2020 school year. Based on the attendance list, it appeared that a number of students were late, skipped and did not attend the Akidah Akhlak learning.

\section{b. Exemplary}

The efforts of Akidah Akhlak teachers in implementing disciplinary values for students include exemplary. If a teacher wants to instill and improve character or commendable morals in students, he should imitate the character of the Prophet. because he is a role model for all mankind.

Teachers are required to have a noble, moral personality, and do positive things in accordance with what is taught to students, both in the form of attitudes, speech and behavior so that they can be good role models for students. This exemplary impact on the behavior of students, because teachers are the second party after parents and families. Thus, the moral values, in this case the discipline that has been taught by the teacher, can be practiced by students on the basis of imitating teacher behavior. If these values are not also practiced by the teacher, it can cause unexpected things such as negative assessments of students to the teacher.

e-ISSN: 2715-4572

p-ISSN: 2716-1439 
For that teacher's behavior must be relevant to what is taught to students.

Mrs. Minarni, as a teacher of Akidah Akhlak, strives for student discipline by providing examples to arrive on time in class, according to her:

I give an example to children through discipline by coming to class on time, for that the children should not be late so that they can manage the time as discipline as possible. Thus, children are expected to appreciate the time in their activities, especially in learning. ${ }^{29}$ Ibu Minarni's statement that she gave an example of discipline when going to class was strengthened by the attendance list of teachers in class XI social science-science 2 .

\section{c. Provide advice and motivation}

The next step is taken by the Akidah Akhlak Teacher in striving for student discipline by providing motivation and advice.

Researchers view that motivation is a very important element as a driving force in doing something to achieve the expected goals. Through motivation and advice, Akidah Akhlak teachers act as tutors who encourage students to realize discipline. Then through the motivation given by the teacher, gradually students have the awareness and ability to motivate themselves in realizing discipline to achieve happiness and success in life. Giving advice should be practiced by Akidah Akhlak teachers by using a polite, gentle language style, carried out in a comfortable place so that

\footnotetext{
${ }^{29}$ Minarni, Guru Akidah Akhlak, "Wawancara", di ruang guru, tanggal 25 September 2019.
}

it touches reason and feelings. This is considered important, because as humans who need guidance, negative things done by students need to be covered so as not to make students feel tense and embarrassed in dealing with the problems faced, both personal issues and problems related to social relationships in the family environment. madrasa, and society.

\section{d. Provide sanctions / penalties}

Apart from giving examples and disciplinary advice to students, the efforts made by Mrs. Minarni to inspire students' discipline by imposing sanctions in the form of not being allowed to enter the Akidah Akhlak lesson. This step is an effort in educating students to be on time in learning to produce individuals who value time in the form of discipline. According to Mrs. Minarni, that:

Students are required to arrive on time, I am very strict about this. So that the children I teach understand that when my class has started, all students are ready for class. Because students were late and had been given a warning regarding this matter, I did not allow them to enter the class. So this way, children will become accustomed to being on time in class. ${ }^{30}$

Based on the interview above, Mrs. Minarni's assertiveness by imposing sanctions in the form of prohibition of following Akidah Akhlak learning in increasing discipline gave positive changes by gradually increasing

\footnotetext{
30Minarni, Guru Akidah Akhlak, "Wawancara", di ruang guru, tanggal 25 September 2019.
} 
some of the disciplinary attitudes of students in following learning.

\section{e. Advice and motivation}

Advice given by Akidah Akhlak teachers to students who have problems with responsibility by repeatedly reminding them to do the assignments given and providing motivation to become a better figure in the future through learning, so they need to have enthusiasm in completing learning tasks.

Ferdiansyah Putra as a student of class XI social science-science 2 said that:

I was absent several times so I didn't do my assignments, Mrs. Minarni often called me to tell me which tasks I had not done, besides that, she often gave advice like what we would be doing in the future if we didn't do our assignments, if you want to be successful you have to study well so that in the future we do not become people who are governed, must be leaders. I am quite motivated to do assignments seeing Mrs. Minarni who is always active to remind us to do assignments. Mrs. Minarni is always active in encouraging students to be active so that there are no empty scores, different from other teachers. 31

The statements that have been expressed by these students illustrate that the increase in students' irresponsible behavior towards the learning tasks given, is strived by the Akidah Akhlak teacher by repeatedly giving advice and motivation to have concern for learning tasks, because responsibility is a form of noble morals that must be possessed by students.

${ }^{31}$ Ferdiansyah Putra, Siswa Kelas XI IIS MAN 2 Kota Palu, "Wawancara", di Ruang Kelas XI IIS 2, Tanggal 23 Januari 2020. f. Making friends as assisting teachers

Akidah Akhlak teachers give responsibility to students who excel in learning to provide assistance to friends who have difficulty doing learning assignments, so that these tasks can be completed, as said by Mrs. Minarni, according to her:

I get around the irresponsible child by asking his smarter friend as an assistant teacher in the class to monitor and help the child in completing study assignments by showing the tasks he has done so that his friends write, so that little or much knowledge can be obserb. ${ }^{32}$

This effort emphasizes the teacher to help care for friends who have difficulty doing assignments. On the one hand, the assisting teacher is fully responsible for the condition of his friend, so that this becomes the motivation to provide maximum assistance in providing solutions to the difficulties experienced by his friends.

\section{g. Sanctions / penalties}

Sanctions given to students who do not do their assignments by calling them to the front of the class and asked to stand, this is in line with what Ferdiansyah Putra said, according to him: "Usually if they don't do the assignment, the sanction given by the teacher is to stand in front of the class" 13

32 Minarni, Guru Akidah Akhlak, "Wawancara", di Ruang Guru, Tanggal 18 Januari 2020.

${ }^{33}$ Ferdiansyah Putra, Siswa Kelas XI IIS MAN 2 Kota Palu, "Wawancara", di Ruang Kelas XI IIS 2, Tanggal 23 Januari 2020.

e-ISSN: 2715-4572

p-ISSN: 2716-1439 
Afifah Indar Syafitri said, Mrs. Minarni was strict, gave punishment, told us to stand with children who did not do their work, friends experienced changes such as Gilang, Aldi Alang, and Abdillah, who were more attentive, by doing their duties. In addition to memorizing the proofs of the Qur'an and Hadith in one paper, they are competing to memorize deposits with the person appointed by the teacher.

Based on observations in class XI social sciences, the writer found that there were some students who did not carry out these tasks as shown in the attached photo documentation, so that Mrs. Minarni as the Akidah Akhlak teacher in this class gave sanctions by calling the students concerned, telling them to stand in front of the class and each must do skot jump as much as 20 times, besides that Mrs. Minarni asked students to do the task and was given until the end of the school hours to be turn in. This is done as an effort to increase the responsibility of students to care about the assignment given.

\section{Conclusions}

The teacher's efforts in improving discipline, honesty, responsibility, and cooperation of students at Madrasah Aliyah 2 Palu through learning Akidah Akhlak are carried out by providing exemplary in terms of time of arrival in class, advice and motivation, sanctions/penalties, making friends of students as assisting teachers, applying the discussion method in learning.

Supporting factors in improving the emotional and spiritual intelligence of students at Madrasah Aliyah 2 Palu, namely the existence of cooperation between Akidah Akhlak teachers and homerooms in terms of handling student problems, enthusiasm and cooperation between students in learning, the existence of the madrasah program. in the form of extracurricular activities, especially those of a religious nature in the form of da'wah activities, tahfiz of the Qur'an, duha prayers, reading the Qur'an in the first hour before learning and student council activities every Friday in the form of fundraising for brothers affected by disaster.

\section{REFERENCES}

Agustian, Ary Ginanjar. Rahasia Sukses Membangkitkan ESQ Power Sebuah Inner Journey Melalui Al-Ihsan. Jakarta: Arga, 2003.

Al-Asyqar, Umar Sulayman. Ikhlas. Terj. Abad Badruzzaman. Ikhlas Memurnikan Niat Meraih Rahmat. Jakarta: Serambi Ilmu Semesta, 2006.

Al-Ausyan, Majid Sa'ud. Multaqa al-Adab as-Syar'iyyah. Terj. Abdurrahman Nuryaman, Paduan Lengkap dan Praktis Adab dan Akhlak Islam Berdasarkan al-Qur'an dan asSunnah. Cet. II; Jakarta: Darul Haq, 2015.

Al-Hasyimi, Muhammad Ali. Jati Diri Muslim. Jakarta: Pustaka AlKautsar, 1999.

Al-Jauziyah, Ibnu Qayyim. Al-Da' wa alDawa': al-Jawab al-Kafi Li-Man Sa'ala 'an al-Dawa' al-Syafi. Terj. Fauzi Bahreisy, Ya Allah Terima Kasih Doaku Dikabulkan. Jakarta: Zaman, 2011. 
Al-Jazairi, Abu Bakar Jabir. Minhajul Muslim. Terj. Fedrian Hasmand, Minhajul Muslim. Jakarta: Pustaka Al-Kautsar, 2015.

Al-Kaaf, Abdullah Zakiy. Etika Islami Bimbingan Awal Menuju Hidayah Ilahi. Bandung: CV Pustaka Setia, 2002.

Al-Miskawaih, Abu Ali Akhmad. Tahdzib Al-Akhlaq. Terj. Helmi Hidayat, Menuju Kesempurnaan Akhlak. Cet. III; Bandung: Mizan, 1997.

An-Nawawi, Abu Zakaria Yahya bin Syaraf bin Hasan bin Husein. Riyadhus Shalihin, ed. Ikhwanuddin. Jakarta: Shahih, 2016.

Asteria, Prima Vidya. Mengembangkan Kecerdasan Spiritual Anak Melalui Pembelajaran Membaca Sastra. Malang: UB Press, 2014.

Auliyah, M. Yaniyullah Delta. Melejitkan Kecerdasan Hati dan Otak Menurut Petunjuk Al-Qur'an dan neurologi (Jakarta: Raja Grafindo Persada, 2005.

Azzet, Akhmad Muhaemin. Mengembangkan Kecerdasan Spiritual Bagi Anak. Jogjakarta: KATAHATI, 2010.

Baihaqi, MIF. Psikologi Pertumbuhan Kepribadian Sehat untuk Mengembangkan Optimisme. Bandung: Remaja Rosdakarya, 2008.

Bashori, Khoiruddin dkk. Pengembangan Kapasitas Guru. Jakarta: PT Pustaka Alvabet, 2015.

Buzan, Tony. The Power Of Spiritual Intelligence. Terj. Alex Tri Kantjono W. dan Febrina Fialita,
Sepuluh Cara Jadi Orang yang Cerdas secara Spiritual. Cet. II; Jakarta: Gramedia Pustaka Utama, 2003.

Danim, Sudarwan. Profesionalisasi dan Etika Profesi Guru. Bandung: Alfabeta, 2010.

Departemen Agama RI, Al-Qur'an dan Terjemahnya. Bandung: Syamil Cipta Media, 2006.

Desmita. Psikologi Perkembangan. Cet. VI; Bandung: Remaja Rosdakarya, 2012.

Dewi, Annisa Anita. Guru Mata Tombak Pendidikan. Sukabumi: Jejak, 2017.

Djamarah, Syaiful Bahri. Startegi Belajar Mengajar. Jakarta: PT. Rieneka Cipta, 2002.

El-Fati, Syarifurrahman. Panduan Lengkap Ibadah Sehari-hari. Jakarta: Wahyu Qolbu, 2014.

Evita, E., Syahid, A., \& Nurdin, N. (2019). Understanding Students' Learning Outcomes Differences Through the Application of the Market Place Activity Type of Cooperative Learning Model and the Application of Conventional Learning Models International Journal of Contemporary Islamic Education, 1(1), 67-85.

Fadhilah, Muhammad. Pendidikan Karakter Anak Usia Dini Konsep dan Aplikasinya dalam PAUD. Jogjakarta: AR-RUZ MEDIA, 2013.

Farid, Ahmad. Al-Bahrur Ra'iq Fiz Zuhdi War Raqa'iq. Terj. Najib Junaidi, Manajemen Qalbu Ulama Salaf. Surabaya: Pustaka eLBA, 2008.

e-ISSN: 2715-4572

p-ISSN: 2716-1439 
Fathurrohman, Muhammad. Belajar dan Pembelajaran Modern. Yogyakarta: Garudhawaca, 2017.

Goleman, Daniel. Emotional Intelligence. Terj. T. Hermaya, Kecerdasan Emosional. Jakarta: Gramedia Pustaka Utama, 1996.

Hammam, Hasan Bin Ahmad. At-tadai: bil istigfar, $d u^{\prime} a$, shadakah, shalat, shaum, Alquran. Terj. Tim Aqwam, Terapi dengan Ibadah. Solo: Aqwam, 2008.

Hermita, Neni. Rimba Hamid, M. Jaya Adipura, Achmad Samsudin. Pembelajaran Berbasis Kecerdasan Jamak di SD. Yogyakarta: Deepublish, 2017.

Hude, M. Darwis Emosi Penjelajah Religio-Psikologi tentang Emosi Manusia di dalam Al-Qur'an. Jakarta: Erlangga, 2006.

Husamah, Yuni Pantiwati, Arina Restina, Puji Sumarsono. Belajar dan Pembelajaran. Cet. II; Malang: UMM Press, 2018.

Ibrahim, T dan Darsono. Membangun Akidah dan Akhlak. Solo: PT Tigaserangkai Pustaka Mandiri, 2009.

Ilahi, Mohammad Takdir. Quantum Parenting: Kiat Sukses Mengasuh Anak secara Efektif dan Cerdas. Jogjakarta: Katahati, 2013.

Iskandar. Metodologi Penelitian Pendidikan dan Sosial. Jakarta: Ikapi, 2013.

Jahja, Yudrik. Psikologi Perkembangan. Cet. IV; Jakarta: Kencana, 2015.

Khalid, Amru Muhammad. Al-Shabar wa al-Dzawq (Akhlaq al-Mu'min). Terj. Syarif Hade Masyah, Sabar dan Bahagia. Cet. II; Jakarta: Serambi Ilmu Semesta, 2006.
Khamim, Nur. Jurnal Pemikiran Danah Zohar dan Ian Marshall Tentang Kecerdasan Spiritual dalam Perspektif Pendidikan Agama Islam. Gresik: Attaqwa, 2016.

Latif, Syahrul Akmal dan Alfin el Fikri. Super Spiritual Quotient (SSQ): Sosiologi Qur'ani. Jakarta: Elex Media Komputindo, 2017.

Maksudin. Desain Pengembangan Berpikir Integratif Interkonektif Pendekatan Dialektik. Yogyakarta: Pustaka Pelajar, 2015.

Margono, S. Metode Penelitian Pendidikan. Cet. II; Jakarta: Rineka Cipta, 2000.

Miles, Matthew B. dan A. Michael Huberman. Qualitative Data Analisis. Terj. Tjecep Rohendi Rohili. Analisis Data Kualitatif: Buku Tentang Metode-Metode Baru. Cet. I; Jakarta: UI Pres, 2005.

Moleong, Lexy J. Metodologi Penelitian Kualitatif. Cet. XIII; Bandung: Remaja Rosdakarya, 2001.

Mualifah. Psycho Islamic Smart Parenting. Jogjakarta: Diva Press, 2009.

Mubayidh, Makmun. Ad-Dzaka' Al-Athif wa Ash-Shihhah Al-Athifiyah. Terj. Muhamad Muchson Anasy, Kecerdasan dan Kesehatan Emosional Anak. Jakarta: Pustaka Al-Kautsar, 2006.

Mujid, Abdul dan Yusuf Mudzakir, Ilmu Pendidikan Islam. Cet. I. Jogjakarta: Graha Ilmu, 2007.

Nata, Abuddin. Manajemen Pendidikan. Bogor: Kencana, 2003.

Nurdin, N., \& Yusuf, K. (2020). Knowledge management lifecycle in Islamic bank: the case of

e-ISSN: 2715-4572

p-ISSN: 2716-1439 
syariah banks in Indonesia. International Journal of Knowledge Management Studies, 11(1), 59-80. https://doi.org/10.1504/ijkms.20 20.105073

Nurdin, N. (2017a). Research in Online Space: The Use of Social Media for Research Setting Jurnal Sistem Informasi (Journal of Information System), 13(1), 67-77.

Nurdin, N. (2017b). To Research Online or Not to Research Online: Using Internet-Based Research in Islamic Studies Context. Indonesian Journal of Islam and Muslim Societies, 7(1), 31-54.

Nurdin, N. (2016). The Roles of Information Technology in Islamic Bank Knowledge Management: A study of Two Syariah Banks in Palu. Hunafa: Jurnal Studia Islamika, 13(2), 181217.

https://doi.org/https://doi.org/ 10.24239/jsi.v13i2.444.181-217

Prawira, Purwa Atmaja. Psikologi Pendidikan dalam Perspektif Baru. Jogjakarta: Ar-Ruzz Media, 2013.

Puspasari, Amaryllia. Emotional Intelligent Parenting: Mengukur Emosional Intelligence Anak dan Membentuk Pola Asuh Berdasarkan Emotional Intelligent Parenting. Jakarta: Elex Media Komputindo, 2009.

Qayyim, Ibnu. Raudhah Al Muhibbin wa Nuzhah Al Musytaqin dalam Al Ahmad, Abdul Aziz bin Abdullah, Ath-Thariq Ila AshShihhah An-Nafsiyyah 'Inda Ibnu Qayyim Al Jauziyyah wa 'Ilm AnNafs. Terj. Muh. Iqbal Kadir,
Kesehatan Jiwa. Jakarta: Pustaka Azzam, 2006.

Riduwan. Metode dan Teknik Menyusun Tesis. Cet. X; Bandung: Alfabeta, 2014.

Rusli, R. (2018). Fikih Ekologi dan Kearifan Tradisional: Tinjauan Terhadap Konsep Ihya' al-Mawat dan Hima. Hunafa: Jurnal Studia Islamika, 5(3), 287-298.

Rusli, R. (2014). Teaching Usul al-Fiqh: A Multicultural Education Model. Al-Tahrir: Jurnal Pemikiran Islam, 14(2), 447-464.

Rusman. Belajar dan Pembelajaran Berorientasi Standar Proses Pendidikan. Jakarta: Kencana, 2017.

Satiadarma, Monty $\mathrm{P}$ dan Fidelis E. Waruwu, Mendidik Kecerdasan. Jakarta: Pustaka Populer Obor, 2003.

Selamet, Kasmuri dan Ihsan Sanusi. Akhlak Tasawuf: Upaya Meraih Kehalusan Budi dan Kedekatan Ilahi. Jakarta: Kalam Mulia, 2012.

Setiawan, M. Andi. Belajar dan Pembelajaran. Ponorogo: Uwais Inspirasi Indonesia, 2017.

Setiawati, Rita dan Jamal Abujundi, KiatKiat Menjadi Guru Pemula yang Hebat. Yogyakarta: Deepublish, 2018.

Shihab, M. Quraish. Wawasan Al-Qur'an tentang Zikir dan Doa. Jakarta: Lentera Hati, 2006.

Shomad, M. Abdul. Mengasah SQ dengan Zikir. Jakarta: Pustaka Ikadi, 2005.

Sukandarrumidi dan haryanto. DasarDasar Penulisan Proposal Penelitian. Cet. II; Yogyakarta: Gajah Mada University Press, 2014.

e-ISSN: 2715-4572

p-ISSN: 2716-1439 
Sukmadinata, Nana Syaodih. Metode Penelitian Pendidikan. Cet. VI; Bandung: Remaja Rosdakarya, 2010.

Sumar, Warni Tune dan Intan Abdul Razak. Strategi Pembelajaran dalam Implementasi Kurikulum Berbasis Soft Skill. Yogyakarta: Deepublish, 2016.

Surakhmad, Winarto. Dasar dan Teknik Reseach. Pengantar Metodologi Ilmiah. Bandung: Torsito, 2000.

Suryani. Hadits Tarbawi Analisis Pedagogis Hadits-Hadits Nabi. Yogyakarta: Teras, 2012.

Suwendra, I Wayan. Metodologi Penelitian Kualitatif dalam Ilmu Sosial, Pendidikan, Kebudayaan dan Keagamaan. Bali: Nilacakra, 2018.

Syafri,Ulil Amri. Pendidikan Karakter Berbasis Al-Qur'an. Jakarta: Rajawali Pers, 2012.

Syafril, Muhammad. Berjamaah Lebih Utama. Jakarta: QultumMedia, 2019.

Syah, Muhibbin. Psikologi Belajar. Jakarta: PT. Raja Grafindo Persada, 2009.

Takdir, Mohammad. Psikologi Syukur. Jakarta: Elex Media Komputindo, 2018.

Thalib, Syamsul Bachri. Psikologi Pendidikan Berbasis Analisis Empiris Aplikatif. Jakarta: Kencana, 2010.

Tokan, P. Ratu Ile. Sumber Kecerdasan Manusia. Jakarta: Grasindo, 2016.

Tridhonanto, Al. Melejitkan Kecerdasan Emosi (EQ) Buah Hati. Jakarta: Elex Media Komputindo, 2009.
Tsamara, Toto. Kecerdasan Rohaniah Transendental Intelegensi. Jakarta: Gema Insan Press, 2001.

Tu'u, Tulus. Peran Disiplin Pada Perilaku dan Prestasi Siswa. Jakarta: Grasindo, 2004.

Uha, Ismail Nawawi. Pendidikan Agama Islam: Isu-Isu Pengembangan Kepribadian Pembentukan Karakter Muslim Kaffah. Jakarta: VIV Press, 2013

Umar, Husein. Metode Penelitian untuk skripsi dan Tasir Bisnis. Cet. IV; Jakarta: PT RajaGrafindo, 2010.

Untara,Wahyu. Kamus Bahasa Indonesia. Edisi revisi. Cet. II; Yogyakarta: Indonesia Tera, 2014.

Utsman, Syamsuddin Muhammad bin. Alkabair. Terj. Abu Zufar Imtihan Asy-Syafi'i, Dosa-Dosa Besar. Cet. I; Solo: Pustaka Arafah, 2016.

Wahyudi, Dedi. Pengantar Akidah Akhlak dan Pembelajarannya. Yogyakarta: Lintang Rasi Aksara Book, 2017.

Yusuf, Syamsul. Psikologi Perkembangan Anak dan Remaja. Cet. VII; Jakarta: Remaja Rosdakarya, 2006.

Yuwono, Budi. SQ Reformation: Rahasia Pribadi Cerdas Spiritual "Genius Hakiki". Jakarta: Gramedia Pustaka Utama, 2010.

Zohar, Danah dan Ian Marshall. SQ: Spiritual Intelligence-The Ultimate Intelligence. Terj. Rahmani Astuti. SQ: Memanfaatkan Kecerdasan Spiritual dalam Berpikir Integralistik dan Holistik untuk Memaknai Kehidupan. Bandung: Mizan, 2002. 